NBSIR 84-2868

\title{
Field Tests of the Smoke Control System At the Bay Pines VA Hospital
}

U.S. DEPARTMENT OF COMMERCE National Bureau of Standards National Engineering Laboratory Center for Fire Research Washington, DC 20234

May 1984

\section{Sponsored by:}

U.S. Veterans Administration Washington, DC 20420 



\section{FIELD TESTS OF THE SMOKE CONTROL SYSTEM AT THE BAY PINES VA HOSPITAL}

John H. Klote

U.S. DEPARTMENT OF COMMERCE

National Bureau of Standards

National Engineering Laboratory

Center for Fire Research

Washington, DC 20234

May 1984

Sponsored by:

U.S. Veterans Administration

Washington, DC 20420

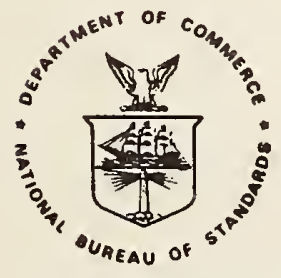

U.S. DEPARTMENT OF COMMERCE, Malcolm Baldrige, Secretary NATIONAL BUREAU OF STANDARDS, Ernest Ambler, Director 



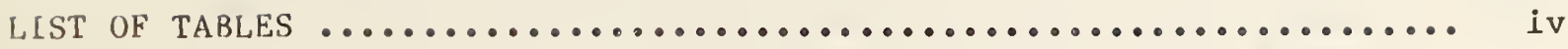

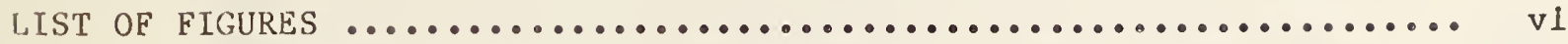

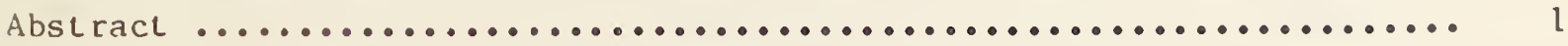

1. intRODUCLION $\ldots \ldots \ldots \ldots \ldots \ldots \ldots \ldots \ldots \ldots \ldots \ldots \ldots \ldots \ldots \ldots \ldots \ldots \ldots \ldots \ldots \ldots$

2. SYSTEM PERFORMANCE ................................ 2

2.l Pressure Differences ............................. 4

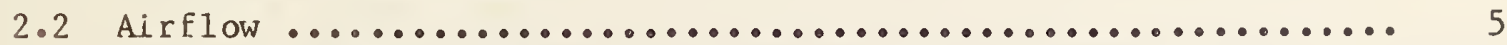

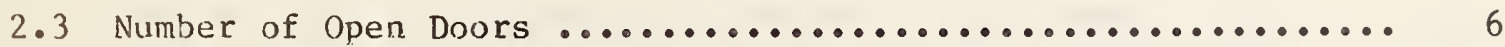

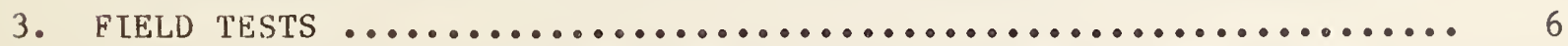

3.1 Bay Pines VA Hospital .......................... 6

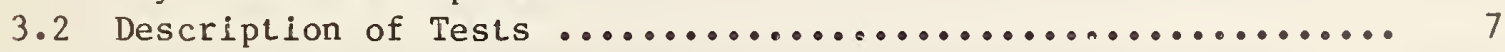

4. DISCUSSION $\ldots \ldots \ldots \ldots \ldots \ldots \ldots \ldots \ldots \ldots \ldots \ldots \ldots \ldots \ldots \ldots \ldots \ldots \ldots \ldots \ldots \ldots . \ldots \ldots$

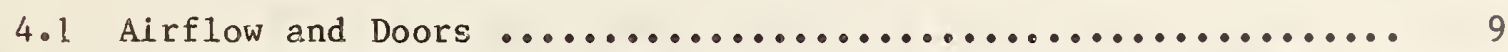

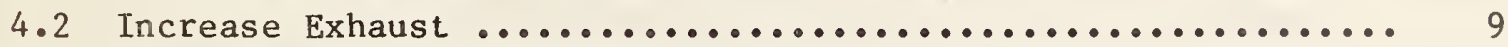

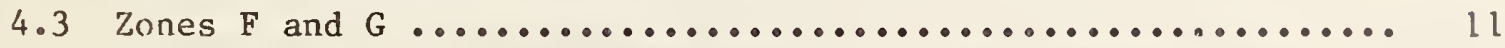

4.4 System Activation ................................ 11

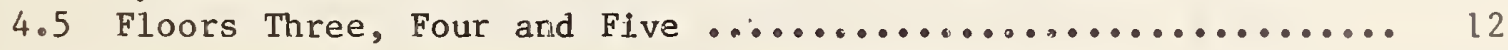

5. RECOMMENDATIONS .................................... 14

5.1 Specific Recommendations ......................... 14

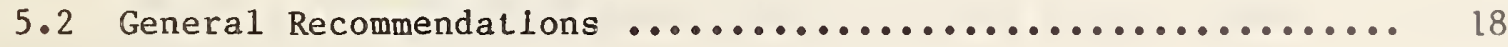

6. ACKNOWLEDGMENTS .......................................... 19

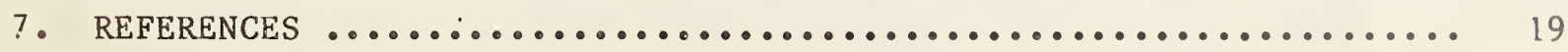

APPENDIX A. Example Calculation of Exhaust Rate for Lobby System .... 20 
Table 1. Smoke control test of VA Bay Pines Hospital, first floor,

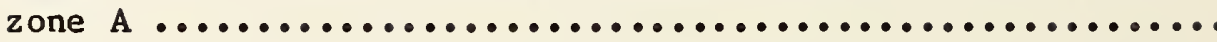

Table 2. Smoke control test of VA Bay Pines Hospital, first floor,

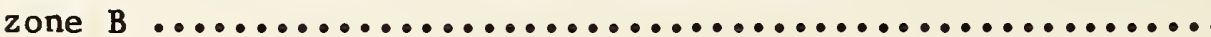

Table 3. Smoke control test of VA Bay Pines Hospital, first floor,

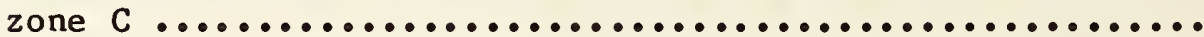

Table 4. Smoke control test of VA Bay Pines Hospital, first floor,

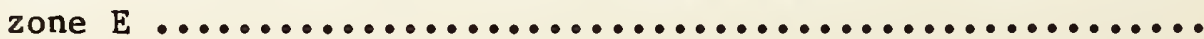

Table 5. Smoke control test of VA Bay Pines Hospital, first floor, zones $F \& G \ldots \ldots \ldots \ldots \ldots \ldots \ldots \ldots \ldots \ldots \ldots \ldots \ldots \ldots \ldots \ldots \ldots \ldots$

Table 6. Smoke control test of VA Bay Pines Hospital, first floor, zone $\mathrm{H}$......................................

Table 7. Smoke control test of VA Bay Pines Hospital, first floor,

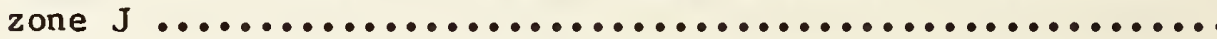

Table 8. Smoke control test of VA Bay Pines Hospital, third floor,

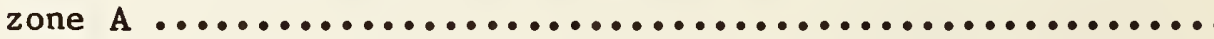

Table 9. Smoke control test of VA Bay Pines Hospital, third floor,

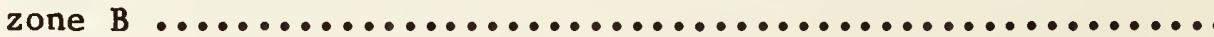

Table 10. Smoke control test of VA Bay Pines Hospital, third floor,

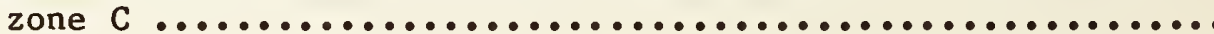

Table 11. Smoke control test of VA Bay Pines Hospital, third floor,

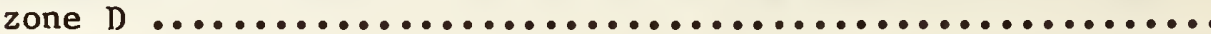

Table 12. Smoke control test of VA Bay Pines Hospital, fourth floor, zone A ......................................

Table 13. Smoke control test of VA Bay Pines Hospital, fourth floor, zone $B$.....................................

Table 14. Smoke control test of VA Bay Pines Hospltal, fourth floor,

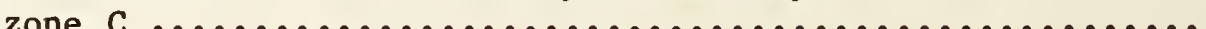

Table 15. Smoke control test of VA Bay Pines Hospital, fourth floor,

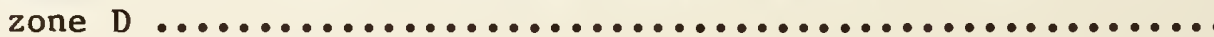

Table 16. Smoke control test of VA Bay Pines Hospital, fifth floor,

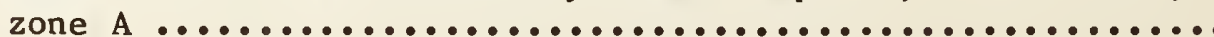


Table 17. Smoke control test of VA Bay Pines Hospital, fifth floor,

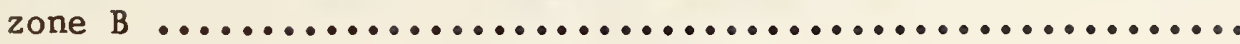

Table 18. Smoke control test of VA Bay Pines Hospital, fifth floor,

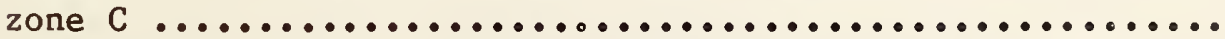

Table 19. Smoke control test of VA Bay Pines Hospital, fifth floor, zone $D$...................................... 


\section{LIST OF FIGURES}

$\underline{\text { Page }}$

Figure 1. Bay Pines VA Hospltal First Floor Plan ............... 40

Figure 2. Bay Pines VA Hospital Second Floor Plan ............... 41

Figure 3. Bay Pines VA Hospital Typical Plan for

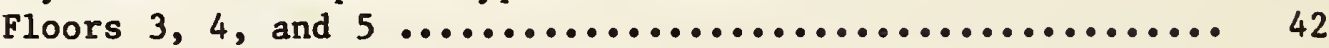

Figure 4. Operations of Double Egress Doors in Smoke Control System ...................................... 
FIELD TESTS OF THE SMOKE CONTROL SYSTEM AT THE BAY PINES VA HOSPITAL John H. Klote

Abstract

The Veterans Administration (VA) has sponsored a project at the Center for Fire Research of the National Bureau of Standards to study smoke control in VA hospitals and to develop new design approaches and methods of acceptance testing. This paper is the first report of this project, and it presents the results of a field test on the VA Bay Pines Hospital. In general the smoke control systems at this hospital performed we11, however, there were some problems. These problems are discussed along with specific recommendations for their corrections and general recommendations to prevent similar problems in future hospitals. It was observed that the double egress doors in the hospital acted in a manner similar to barometric dampers to limit pressure differences.

Key words: air movement; field tests; hospitals; interstitial space; pressurization; smoke control; smoke detector.

\section{INTRODUCTION}

Smoke is recognized as the major killer in fire situations [1]*. Smoke often migrates to building locations remote from the fire space, threatening life and damaging property. As a solution to the smoke problem, the concept of smoke control has developed in recent years. Smoke control makes use of

ॠFigures in brackets refer to references at the end of this paper. 
mechanical fans to produce airflows and pressure differences that can control smoke movement.

This paper is a report of the initial effort of a project sponsored by the U.S. Veterans Administration (VA) to study smoke control in VA hospitals and develop new design approaches and methods of acceptance testing. This paper describes field tests of the smoke control systems at the VA hospital in Bay Pines, Florida. It will be shown that in general these systems performed we11, however, there were some problems. To overcome these problems, specific recommendations are made, and general recommendations are made that should prevent similar problems in future hospitals. In addition to the field tests described herein, tests were performed to evaluate the wind effects on a smoke control system at this hospital. A report of these wind effects is forthcoming •

In this paper, the term "smoke" is used in accordance with the ASTM and NFPA definitions which state that smoke consists of the airborne solid and 1iquid particulates and gases evolved when a material undergoes pyrolysis or combustion $[2,3]$.

\section{SYSTEM PERFORMANCE}

The fire emergency procedure in hospitals throughout the United States including VA hospitals is essentially a plan of horizontal evacuation. Each floor of a hospital is divided into a number of zones, separated from one another by fire walls and fire doors. Generally, nurses are trained to evacuate any patients from the room of fire origin and then close the door. 
Then the patients in the zone which includes the fire room are evacuated to other zones on that floor. Because of vertical smoke movement, similar horizontal evacuation may be necessary on floors other than the fire floor. The closed doors between the fire and the occupants tend to retard fire spread and smoke movement, ideally allowing sufficient time for fire fighters to extinguish the fire. There is the option for vertical evacuation from these other \%ones if such an extreme measure be deemed necessary.

This approach has the drawback that smoke movement through building cracks and gaps around doors is likely. The effectiveness of a barrier in limiting smoke movement depends on the leakage paths in the barrier and on the pressure difference across the barrier. The pressure difference depends on stack effect, buoyancy, wind and the heating, ventilation and air conditioning (HVAC) system whether under normal operation or in the smoke control mode.

The concepts of zoned smoke control as described in the ASHRAE smoke control manual [4] can be employed to provide pressure differences and airflows to limit the smoke movement to the zone in which the fire exists.

Because smoke control is a new field, consensus has not been reached as to what constitutes reasonable design parameters. The ASHRAE smoke control design manual lists the following areas for which design parameters must be established: 
l. leakage areas

2. weather data

3. pressure differences

4. airflow

5. number of doors open in the smoke control system.

The reader is referred to the general discussion of leakage areas and weather data provided in the ASHRAE smoke control manual.

\subsection{Pressure Differences}

It is appropriate to discuss both maximum and minimum allowable pressure differences across the boundaries of the smoke control zones. The maximum allowable pressure difference should be a value that does not result in an excessive door-opening force, but it is difficult to determine what constitutes excessive door opening forces. Section 5-2.1.1.4.3 of the National Fire Protection Association (NFPA) Life Safety Code [5] states that the force required to open any door in a means of egress shall not exceed $222 \mathrm{~N}$ (50 1 b). Because of the difficulty of evacuating a disabled patient and because exposure to smoke can adversely affect a person's physical ability, a lower value than $222 \mathrm{~N}$ (50 1b) seems appropriate. For a door opening force of $111 \mathrm{~N}$ (25 1b) and a force of $31 \mathrm{~N}(7 \mathrm{1b})$ to overcome the door closer, a door $1.12 \mathrm{~m}$ ( $44 \mathrm{in}$ ) wide and $2.13 \mathrm{~m}(7 \mathrm{ft}$ ) high would have a maximum allowable pressure difference of $63 \mathrm{~Pa}\left(0.25\right.$ in $\left.\mathrm{H}_{2} \mathrm{O}\right)$. For purposes of discussion, this will be used as the maximum allowable pressure difference in this paper. 
In this paper, the criterion for a minimum allowable pressure difference is that no smoke leakage* shall occur from the smoke zone (one in which there is a fire) to an adjacent zone. The smoke control system must produce sufficient pressure differences so that it is not overcome by the forces of wind, stack effect, or buoyancy of hot smoke.

Because new VA hospitals are sprinklered, the minimum pressure difference of $5 \mathrm{~Pa}\left(0.02\right.$ in $\left.\mathrm{H}_{2} \mathrm{O}\right)$ suggested in the ASHRAE manual (section 2.9.2) for sprinklered spaces is used in this paper as the minimum pressure difference to overcome the effects of buoyancy of smoke. Theoretically the smoke control system should be able to produce at least this pressure under design conditions of wind and stack effect with a broken window in the fire compartment. Such an analysis can be performed by the computer program described in the ASHRAE design manual.

\subsection{Alrflow}

Airflow through an open doorway can control smoke movement if the average velocity is of sufficient magnitude. In a sprinklered bullding, it might be considered that the smoke away from the immediate fire area would be cooled to near ambient temperature by the water spray from the sprinklers. In such a case the ASHRAE manual recommends a design velocity in the range of 0.25 to $1.25 \mathrm{~m} / \mathrm{s}$ ( 50 to $250 \mathrm{fpm}$ ).

It is obvious that a smoke control system can meet its objectives of reduced fire deaths, injuries and property damage due to smoke, even if a small amount of smoke infiltrates the protected areas. 


\subsection{Number of Open Doors}

During a fire situation, the doors in boundaries of a smoke zone will be closed except for short intervals when a person is being evacuated or when a rescuer or fire fighter enters the smoke zone. Obviously, smoke infiltration into the protected zones is significantly less than for doors that are held open. For purposes of discussion in this paper, it will be considered that smoke leakage through such intermittently open doors is insignificant. However, the airflow produced by the smoke control system can be sufficient to hold doors open (section 4.1 ).

\section{FIELD TESTS}

\subsection{Bay Pines VA Hospital}

The Bay Pines VA Hospital consists of five stories each with an interstitial space above for distribution of heating, ventilation, air conditioning, plumbing and electrical systems. These utilities are systematically organized according to a standard plan, which is part of the VA hospital building system [6]. The interstitial space is approximately $2.1 \mathrm{~m}(7 \mathrm{ft}$ ) in height with its own gypsum floor. Each story of the hospital is divided into a number of service modules, each served by its own variable volume HVAC system and each having its own supply and exhaust air handling units utilizing a heat wheel between them for energy conservation.

The smoke control system is designed so that each HVAC zone (see figures 1-3) is a smoke control zone. During a fire situation, the HVAC system, controlled by a computer, is put in the following smoke control mode: 
1. The supply fan to the zone in which the fire exists (smoke zone) is shut off.

2. The exhaust fans to the adjacent zones on the fire floor and to zones directly above and below are shut off.

Thus air is being exhausted from the smoke zone and surrounding zones are being pressurized. The intent is that smoke movement will be 1 imited to the smoke zone.

\subsection{Description of Tests}

Tests were performed for which individual zones were placed in the smoke control mode and the resulting pressure differences were measured. Data from these tests are 1isted in tables 1-19. All the pressure differences recorded were on the same floor as the smoke zone. Pressure differences are listed such that positive values represent air flow in the direction of the smoke zone. For example, in the test of zone A of the first floor (figure 1), the smoke control system produced $12 \mathrm{~Pa}\left(0.05\right.$ in $\mathrm{H}_{2} \mathrm{O}$ ) (table 1 ) under normal operation from zone B to zone A at corridor 4. This pressure difference indicates flow to zone A which is the smoke zone. In some cases the flow was away from the smoke zone. Accordingly, the corresponding pressure differences in the tables are negative.

Smoke control systems were tested in every zone on the first, third, fourth and fifth floors. Tests were omitted on the second floor because of the disruption they would cause to surgery and intensive care. Further, to 
prevent disruption of the second floor, no second floor exhaust fans were shut off during tests of first or third floor smoke control systems. It is belleved that because of the unusually tight construction of the building floor slabs and the interstitial space floor slabs, pressurization of the spaces above and below the smoke zone is not essential. Visual inspection of these slabs impressed the author and the other members of the test team as to how tightly they were constructed. To confirm the effect of tight construction, a test was conducted on the fourth floor because this was the only floor where it was possible to shut off the exhaust fans on both the floors above and below. Because all the zones on the fourth floor would have been equally appropriate, zone B was arbitrarily selected. Zone B on the fourth floor was tested in an increased exhaust, smoke control mode (see section 4.2) with and without pressurization of the floors above and below. The results of these tests (table 13) indicate that pressurization above and below had no significant effect on the pressure differences produced by the smoke control system for this hospital.

Pressure difference fluctuations did not exceed $2.5 \mathrm{~Pa}\left(0.01\right.$ in $\left.\mathrm{H}_{2} \mathrm{O}\right)$, so only average values are listed in the tables. Also, during all of the tests reported herein, the building windows and doors were closed and the wind was relatively calm; accordingly, wind data is not listed in the tables. In all these tests the difference between the indoor and outdoor temperature was very small. The implications of these limited test conditions are discussed in section 4.2 . 


\section{DISCUSSION}

\subsection{Airflow and Doors}

At numerous locations throughout the hospital there are double egress doors as illustrated in figure 4. Upon fire detection, these doors close automatically and low airflow towards the fire through cracks around the doors (and through construction cracks) acts to prevent smoke backflow to the protected spaces. These doors act to prevent excessive pressures in the same manner as a barometric damper. If the airflow increases, the pressure across the door increases. When the pressure difference is sufficient to overcome the force of the automatic door closer, the door opens slightly, the pressure difference drops and an equilibrium position is achieved with the door 25 to $100 \mathrm{~mm}$ ( 1 to $4 \mathrm{in}$ ) open. Examination of the test data (tables 1-19) shows that the pressure across such open doors falls within a range of 7.5 to $30 \mathrm{~Pa}$ $\left(0.03\right.$ to 0.12 in $\left.\mathrm{H}_{2} 0\right)$. From this, the air flow equation (ASHRAE smoke control manual, section 2.3 .2 ) indicates that the average velocity through these doorways is 2.3 to $4.5 \mathrm{~m} / \mathrm{s}$ (450 to $900 \mathrm{fpm}$ ). These values are all well above the design velocity range, and accordingly would prevent smoke infiltration into the protected zones.

\subsection{Increase Exhaust}

In the smoke control mode, the exhaust fan drew air from the interstitlal space as well as the smoke zone. This interstitial space exhaust is required by the Life Safety Code [7] section 12-3.6.1 Exception No. I(c) for hospltals where the corridor walls do not extend through the interstitlal space to the 
underside of the roof or floor slab above. It is believed that the intent of the interstitial exhaust was to produce pressure differences such that any smoke within the interstitial space would not flow into nonsmoke zones. However, it was a concern that diverting a signiflcant portion of the exhaust air from the smoke zone would adversely affect the performance of the smoke control system.

Most of the tests were performed with normal smoke control operation and with an increased smoke zone exhaust. The smoke zone exhaust was increased by blanking off the large interstitial space exhaust inlet located in the interstitial space near the mechanical room. In the majority of the cases, the pressure differences were significantly increased by increasing the smoke zone exhaust. Additionally, because of the tendency of the bidirectional doors to act like barometric dampers, excessive pressures were never encountered.

One might feel that even without increased exhaust, the pressure differences are generally above the minimum allowable pressure difference and should be acceptable. However, these pressure differences were measured without the influence of stack effect or wind. Such influences could be increased in the case of a broken fire compartment window. Even though this topic is the subject of a another effort of this overall project, it is obvious that increased flows and increased pressure differences due to increased exhaust provide an added margin which will help prevent smoke control system failure due to wind or stack effect. 


\subsection{Zones $\mathrm{F}$ and $\mathrm{G}$}

Zones F and G, Ambulatory Care Clinic, (see figure 1) on the first floor warrant special attention because they are completely open to each other at several locations. When zone $F$ was placed in the smoke control mode, the air velocity from zone $G$ to zone $F$ was almost unnoticeable. This would be no deterent to smoke flow into zone $G$ and then to other areas of the hospital.

For this case, the two HVAC zones should be treated as one zone for smoke control purposes. Tests of the combined zones (table 5) indicate that they maintain pressure differences in the range 25 to $30 \mathrm{~Pa}\left(0.10\right.$ to 0.12 in $\left.\mathrm{H}_{2} \mathrm{O}\right)$ with respect to zones $\mathrm{A}$ and $\mathrm{H}$. These pressure differences are many times larger than the minimum pressure differences.

\subsection{System Activation}

The smoke control systems are activated by smoke detectors located in the return ducts. When this hospital was designed this was a common practice. The original intent of smoke detectors in the return ducts is to divert smoke laiden air to the outside*. As stated in the ASHRAE smoke control manual, smoke detectors in ducts are not recommended for smoke control system activation because of their long response time and the maintenance problem of clogging with airborne contaminants.

\footnotetext{
* The intent of the detector in the supply duct is to shut down the HVAC system and to prevent circulation of smoke from a HVAC fire or from an exterior source.
} 
The doors between zones are controlled by smoke detectors. However, activation of the smoke control system from these detectors would be inappropriate because it would be impossible to know which zone was the smoke zone based on a signal from a detector located at the boundary between two zones.

Either open area smoke detectors or the sprinkler system or both could be used for smoke zone identification and automatic activation.

\subsection{Floors Three, Four and Five}

In a fire situation on a floor or a hospital with patient rooms, the smoke control system should operate so that it compliments the horizontal evacuation discussed in section 2. The two fire scenarios described below evaluate the performance of the smoke control system on the floors with patient rooms. The first fire scenario involves a fire in one of the four wings (figure 3). For example, consider a fire in a patient room or other space on floor four in wing A. Due to smoke levels in the corridor the wing is evacuated. Evacuation would be first to the north lobby and possibly later to the south lobby. Operation of the smoke control system should be such that the north lobby is pressurized with respect to wing $A$. The test data (table 12) show that this would be the case. Further, the test data (tables 8-19) show that the smoke control systems are capable of maintaining similar pressurization for each wing for the top three floors.

\footnotetext{
Closing the burn room door is widely recognized as a method to reduce smoke concentrations in corridors. However, in real fire incidents, patient room doors have been left open due to oversight or because the fire intensity made door closing impossible. Further, some spaces, such as the nurse station, have no doors.
} 
The second scenario consists of a fire in one of the lobbies or in an adjacent room such as a lounge. For example, consider a fire in a lounge opening onto the north lobby of the fourth floor (figure 3 ). The tests of the smoke control system (table 12) Indicate that the south lobby and wing D would be pressurized relative to the north lobby. These pressures would protect wing $D$ and the south lobby from smoke migration. Unfortunately, the north lobby would be overpressurized with respect to wing $A$. Thus, the action of the smoke control system would be to force smoke into wing A. This situation is compounded further because the only route for horizontal evacuation of wing A is through the north lobby, which would be smoke logged. The reason these flow patterns occur is that smoke control zone A incorporates both wing A and the north lobby. If the north lobby were exhausted and wings $A$ and $D$ and zone $B$ were pressurized then this problem would be eliminated. This problem is not just limited to the fourth floor north lobby, but is common to the north and south lobbies on the third, fourth and fifth floors (tables 8, 9, 12, 13, 16, and 17).

Several negative pressure differences were measured in the tests of zones $\mathrm{C}$ and $\mathrm{D}$ on the third, fourth and fifth floors (tables 10, 11, 14, 15, 18 and 19). In keeping with our sign convention, negative pressure differences indicate an air flow away from the smoke zone. For example, zone $C$ of the third floor (table 10) has negative pressure differences at three locations. These indicate flow from the south lobby to the south elevator shaft, to stairwell 2, and to the north lobby. This airflow is to be expected since zone B which includes the south lobby was pressurized. The crucial barrier for smoke control is between wing $C$ and the south lobby where slgnlficant pressure differences occur. It can be observed from table 10 that Increasing, 
the exhaust of the smoke zone increases this crucial pressure difference. This same reasoning explains the other negative pressure differences encountered in the tests of zones $C$ and $D$ on floors three, four and five.

\section{RECOMMENDATIONS}

The recommendations from this study fall into two categories. First, those that apply specifically to the Bay Pines VA Hospital and secondly, general recommendations that apply to the design of new hospitals. It should be noted that future efforts in this project will undoubtedly result in additional information which may affect the recommendations which follow.

\subsection{Specific Recommendations}

In general the performance of the smoke control system was quite good, however, to overcome specific problems five recommendations are made. Recommendation C lists four different alternative solutions which can be considered.

A. It is recommended that smoke control zones $F$ and $G$ on the first floor be combined into one smoke control zone. Because at many locations these zones are completely open to each other, the use of pressurization to achieve smoke control between these zones is impossible. However, when the two zones are combined, pressurization of surrounding areas is readily achieved. 
B. It is recommeded that consideration be given to modifying the smoke control systems so that activation of smoke control on the first or third floors will not cause pressurization of any second floor zone. Such pressurization would have essentially no benefit with regard to smoke control, however, it could cause unnecessary disruption to surgery and intensive care.

C. Is is recommended that smoke control zones A and B on floors three, four and five be modified so that upon fire detection in the north lobby or the south lobby, air will be exhausted only from that lobby, with the other lobby and the adjacent wings pressurized. For example, this will prevent the smoke control system from forcing smoke into wing $A$ in the event of a fire in the north lobby or a space open to it such as one of the lounges. The same is true for wing $B$ and the south lobby. Example calculations to determine the exhaust fan capacity are provided in appendix A. Some alternative modifications that might be considered are:

1. Damper Control. The alternative would consist of installing dampers so that the existing fans could be used. For example, to exhaust the north lobby the exhaust fans and ducts of smoke zone A would be used. A large number of dampers would be needed to shut off exhaust intakes in wing A. Further, a damper would be needed to shut off the supply to the north lobby. 
2. Window Vents. This alternative consists of pressurizing the wings adjacent to the north (south) lobby and the adjacent lobby and venting the north (south) lobby. A damper in the supply duct to the north (south) lobby would prevent supply air from entering this lobby. The vents, which could be located in the windows, would open automatically upon activation of the smoke control system. A damper in the supply duct to the north (south) lobby would be needed. Because this system has vents in vertical walls, performance would be highly dependent on wind conditions, making this the least effective of the systems listed here.

3. Ceiling Fan. Pressurization of surrounding areas would be the same as alternative 2, but a ceiling mounted exhaust fan from the north (south) lobby to the interstitial space would be used. Smoke could be exhausted from the interstitial space by an exhaust fan in mechanical room $A(B)$. This would require additional control dampers in the exhaust system. Even though this system has the same potential for producing reliable pressurization as alternative 1 , it has the disadvantages that It contaminates the interstitlal space with smoke and probably subjects the ceiling fan to high temperatures.

4. Ducted Exhaust. An improvement on alternative 3 is to locate the exhaust $f$ an in one of the mechanical rooms and duct the lobby air to it. A cursory inspection reveals that there should be sufficient space for such a duct in the interstitial space. 
This alternative has simple controls, eliminates the interstitial space contamination problem of alternative 3 , and has the same potential for producing rellable pressurization as alternatives 1 and 3 . This alternative also has the advantage over alternative 3 in that smoke cooled by heat transfer in the duct reduces the concern of temperature endurance of the fan.

D. Activation of the smoke control system depends upon fire detection which should be by open area smoke detectors, by flow switches in the sprinkler system or by both. The use of flow indicators would require some logic circuits or reliance on the building's computer control to determine the location of the fire.

E. It is recommended that consideration be given to increasing the smoke zone exhaust by closing the dampers to the interstitial space exhaust. This will provide an increased exhaust flow rate which will help prevent smoke control system failure due to wind or stack effect (section 4.2). Because of tight construction of the building floor slabs and interstitial space floor slab, it appears that interstitial space exhaust would be of benefit only when smoke would get into the interstitial space. However, interstitial space exhaust can be achieved without use of the smoke zone exhaust fan by using an exhaust fan serving one of the nonsmoke zones. 


\subsection{General Recommendations}

A. When two adjacent HVAC zones have large openings to one another, they should be considered one zone for smoke control purposes.

B. The fan used to exhaust the smoke zone should not simultaneously be used to exhaust the interstitial space. This reduces the exhaust from the smoke zone and thus reduces the effectiveness of the smoke control system. Interstitial space exhaust can be achieved to an even greater extent by using the full capacity of an exhaust fan from another zone.

C. Criteria for determination of smoke zone arrangements need to be developed such that the problems that exist in the north and south lobbies on floors three, four and five do not reoccur in future designs. Possibly designs should be such that a single fire can not block the only means of horizontal exit from a wing. Information needed for the development of such criterla is a future subject of this project.

D. Smoke control system activation should be by means of open area detectors, sprinkler water flow or both.

E. It is recommended that the smoke zone be exhausted by the full capacity of the exhaust fan normally serving the smoke zone. 


\section{ACKNOWLEDGMENTS}

Thanks are due to the staff of the VA Bay Pines Hospital for their aid and cooperation during these tests. Appreciation is expressed to William Schmidt of the Veterans Administration and to Richard Grot, Robert Ha11, and Douglas Pruit of the Center for Building Technology of the National Bureau of Standards for their considerable help during testing.

\section{REFERENCES}

[1] Berl, W.G. and Halpin, B.M., Human Fatalities from Unwanted Fires, Johns Hopkins APL Technical Digest, Vol. 1, No. 2, p. 129-134, 1980.

[2] Annual Book of ASTM Standards, Part 18, ASTM E176-80, American Society for Testing and Materials, Philadelphia, PA, 1980.

[3] Standard for the Installation of Alr Conditioning and Ventilating Systems, NFPA 90A-1981, National Fire Protection Association, Inc., Quincy, MA, 1981.

[4] Klote, J.H. and Fothergill, J.W., Design of Smoke Control Systems for Buildings, American Soclety of Heating, Refrigerating, and AlrConditioning Engineers, Atlanta, GA, 1983.

[5] Code for Safety to Life from Fire in Bulldings and Structures, NFPA 101-1981, Quincy, MA, National Fire Protection Assn., 1981.

[6] Development Study - VA Hospital Bullding System, U.S. Government Printing Office, Washington, DC, August 1977. 
APPENDIX A. Example Calculation of Exhaust Rate for Lobby System

The exhaust rate needed for the lobby smoke control system (section 5.1.B) can be calculated as follows:

1. Estimate Flow Areas. Estimate the total flow area from the pressurized spaces to the lobby. For example, if three doors are held $100 \mathrm{~mm}$ ( $4 \mathrm{in}$ ) open by air flow, the total area of the opening at the edge of the doors would be about $0.65 \mathrm{~m}^{2}$ $\left(7.0 \mathrm{ft}^{2}\right)$. Additional flow area exists in the form of gaps around closed doors and construction cracks. These can be allowed for by adding $0.20 \mathrm{~m}^{2}(2.1 \mathrm{ft})$ to get the flow area a total estimated flow area of $0.85 \mathrm{~m}^{2}\left(9.1 \mathrm{ft}^{2}\right)$.

2. Estimate Pressure Difference. Based on test data in tables 8 to 19 , the pressure difference for doors held open by airflow is estimated at $25 \mathrm{~Pa}\left(0.10\right.$ in $\left.\mathrm{H}_{2} \mathrm{O}\right)$.

3. Calculate Alrflow Rate. Based on the flow area and the pressure difference, the exhaust fan flow rate can be calculated as described in the ASHRAE smoke control manual section 2.3.2. For the above example this would be $3.5 \mathrm{~m}^{2} / \mathrm{s}$ (7500 $\mathrm{cfm})$. 
Table 1. Smoke control test of VA Bay Pines Hospital, first floor, zone A

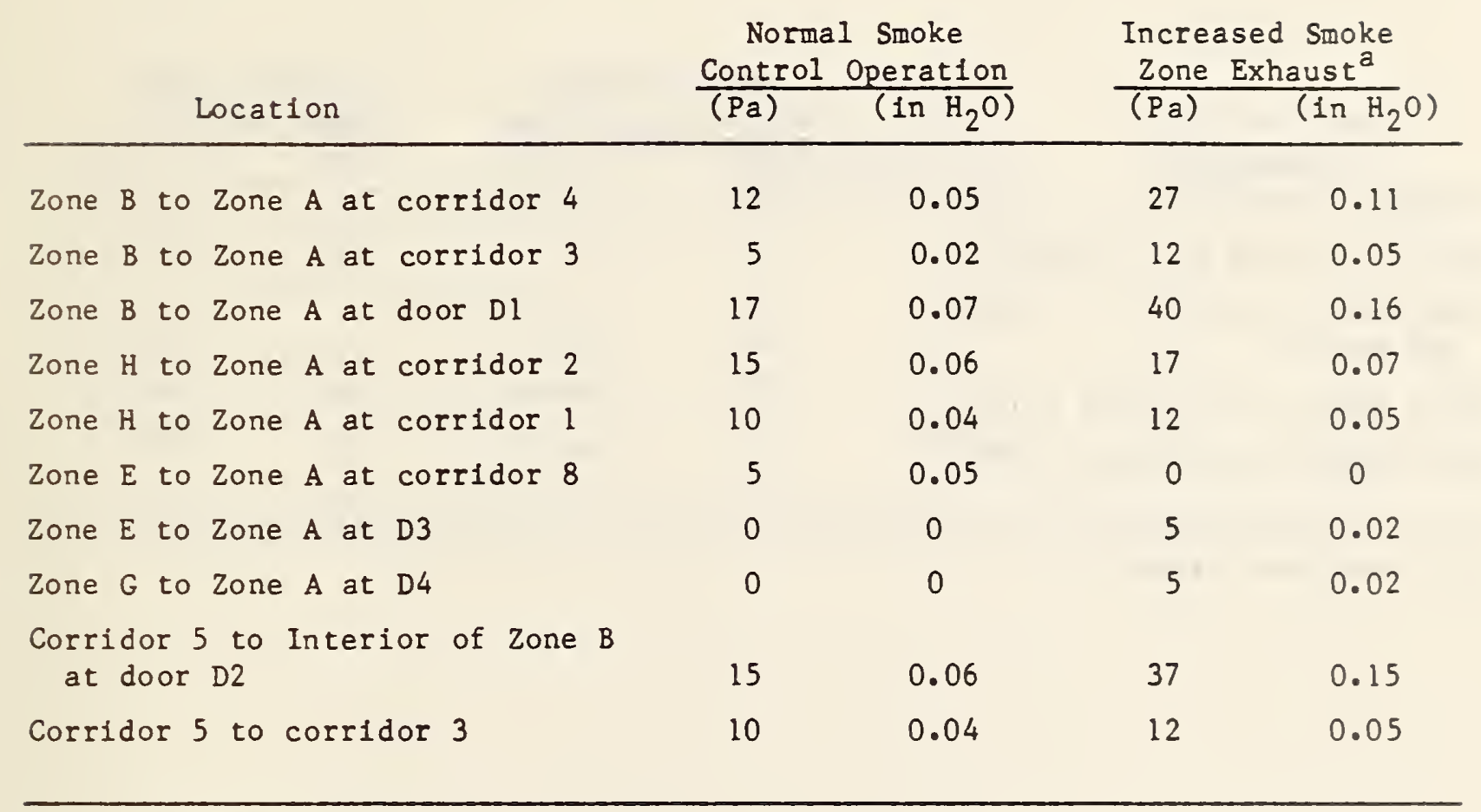

For notes see table 19. 
Table 2. Smoke control test of VA Bay Pines Hospital, first floor, zone B

\begin{tabular}{ccccc} 
Location & $\begin{array}{c}\text { Normal Smoke } \\
\text { Control Operation }\end{array}$ & $\begin{array}{c}\text { Increased Smoke } \\
\text { Zone Exhausta }\end{array}$ \\
\hline $\begin{array}{l}\text { Zone E to Zone A at corridor } 7 \\
\text { Main lobby to Director's suite }\end{array}$ & -7 & -0.03 & -7 & -0.03 \\
at door D5 & 12 & 0.05 & 7 & 0.03 \\
Main lobby to corridor 9 (DO) ${ }^{\mathrm{b}}$ & 12 & 0.05 & 7 & 0.03 \\
Main lobby to corridor 9 (DC) & 27 & 0.11 & 20 & 0.08 \\
\hline
\end{tabular}

For notes see table 19. 
Table 3. Smoke control test of VA Bay Pines Hospital, first floor, zone $C$

\begin{tabular}{lcccc} 
& \multicolumn{2}{c}{$\begin{array}{c}\text { Normal Smoke } \\
\text { Location }\end{array}$} & $\begin{array}{c}\text { Increased Smoke } \\
\text { Zone Exhaust }\end{array}$ \\
\hline Zone B to Zone C at door D6 & 15 & 0.06 & 42 & 0.17 \\
Zone D to Zone C & 22 & 0.09 & 32 & 0.13 \\
$\begin{array}{l}\text { Corridor 7 to Dietetic Services } \\
\text { at door D7 }\end{array}$ & 2 & 0.01 & 27 & 0.11 \\
\hline
\end{tabular}

For notes see table 19. 
Table 4. Smoke control test of VA Bay Pines Hospital, first floor, zone $E$

\begin{tabular}{lcccc} 
& Location & $\begin{array}{c}\text { Normal Smoke } \\
\text { Control Operation }\end{array}$ & \multicolumn{2}{c}{$\begin{array}{c}\text { Increased Smoke } \\
\text { Zone Exhaust }\end{array}$} \\
\hline Zone A to Zone E at corridor 8 & 25 & 0.10 & 40 & 0.16 \\
Zone B to Zone E at corridor 7 & 20 & 0.08 & 20 & 0.08 \\
Corridor 7 to Pharmacy & 7 & 0.03 & 32 & 0.13 \\
\hline
\end{tabular}

For notes see table 19. 
Table 5. Smoke control test of VA Bay Pines Hospital, first floor, zones $F \& G$

\begin{tabular}{lccccc} 
Location & $\begin{array}{c}\text { Normal Smoke } \\
\text { Control Operation }\end{array}$ & \multicolumn{2}{c}{$\begin{array}{c}\text { Increased Smoke } \\
\text { Zone Exhaust }\end{array}$} \\
\hline to Zones F \& G at door D9 & 25 & 0.10 & 27 & 0.11 \\
to Zones F \& G at door D4 & 30 & 0.12 & 30 & 0.12
\end{tabular}

For notes see table 19. 
Table 6. Smoke control test of VA Bay Pines Hospital, first floor, zone $H$

\begin{tabular}{|c|c|c|c|c|}
\hline Location & $\begin{array}{r}\text { Nor } \\
\text { Contr } \\
(\mathrm{Pa})\end{array}$ & $\begin{array}{l}\text { Smoke } \\
\text { Operation } \\
\left(\operatorname{In~} \mathrm{H}_{2} \mathrm{O}\right)\end{array}$ & $\begin{array}{l}\text { Incre } \\
\text { Zone } \\
(\mathrm{Pa})\end{array}$ & $\begin{array}{l}\text { ased Smoke } \\
\text { Exhaust }{ }^{a} \\
\left(\text { in } \mathrm{H}_{2} \mathrm{O}\right)\end{array}$ \\
\hline Zone $G$ to Zone $H$ at door $D 9$ & 15 & 0.06 & 25 & 0.10 \\
\hline Zone $\mathrm{G}$ to Zone $\mathrm{H}$ at door $\mathrm{DlO}$ & 17 & 0.07 & 20 & 0.08 \\
\hline Zone A to Zone $\mathrm{H}$ at corridor 1 & 7 & 0.03 & 17 & 0.07 \\
\hline Zone A to Zone $\mathrm{H}$ at corridor 2 & 17 & 0.07 & 17 & 0.07 \\
\hline Zone G to corridor 5 & 0 & 0 & 10 & 0.04 \\
\hline Corridor 3 to corridor 5 & 10 & 0.04 & 7 & 0.03 \\
\hline Corridor 4 to corridor 5 & 22 & 0.09 & 10 & 0.04 \\
\hline Corridor 8 to corridor 5 & 0 & 0 & 0 & 0 \\
\hline
\end{tabular}

For notes see table 19. 
Table 7. Smoke control test of VA Bay Pines Hospital, first floor, zone $\mathrm{J}$

Normal Smoke Control Operation

Location ( $\mathrm{Pa}) \quad\left(\right.$ In $\left.\mathrm{H}_{2} \mathrm{O}\right)$

Zone $\mathrm{E}$ to Zone $\mathrm{J}$ at corridor 8 $12 \quad 0.05$

Outside to Zone E

$5 \quad 0.02$

For notes see table 19. 
Table 8. Smoke control test of VA Bay Plnes Hospital, third floor, zone A

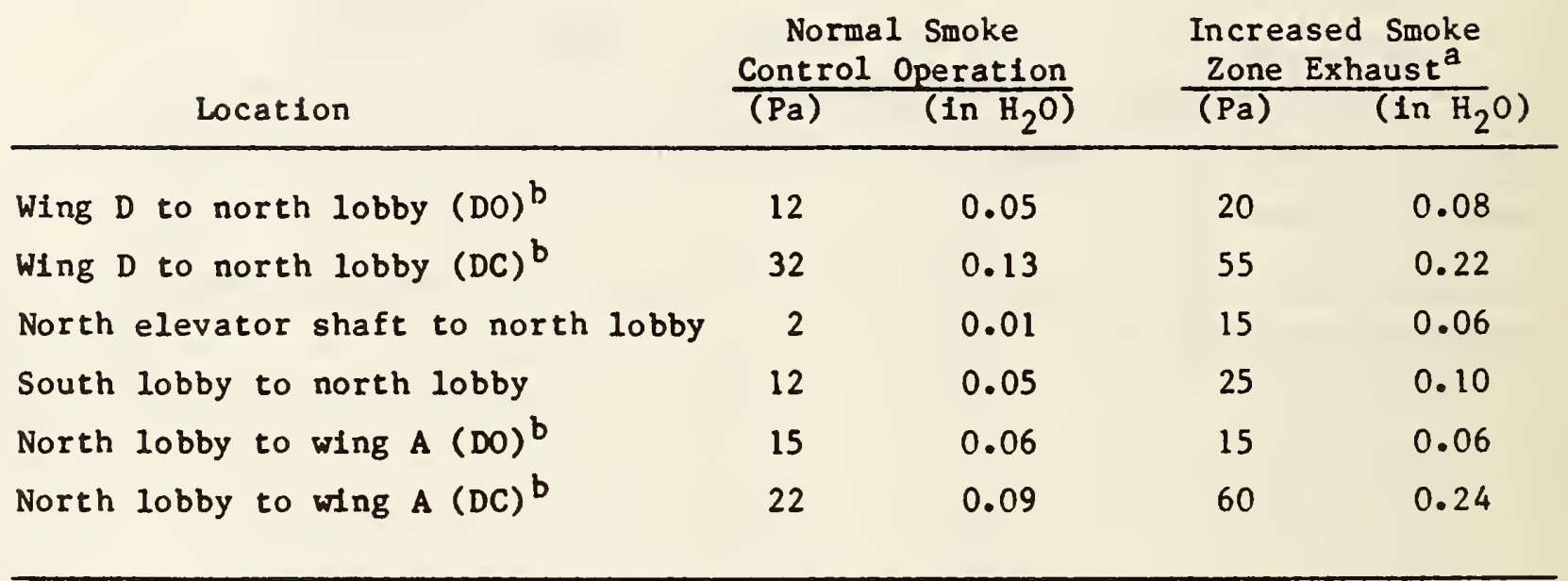

For notes see table 19. 
Table 9. Smoke control test of VA Bay Pines Hospital, third floor, zone $B$

\begin{tabular}{|c|c|c|c|c|}
\hline \multirow[b]{2}{*}{ Location } & \multicolumn{2}{|c|}{$\begin{array}{c}\text { Normal Smoke } \\
\text { Control Operation }\end{array}$} & \multicolumn{2}{|c|}{$\begin{array}{c}\text { Increased Smoke } \\
\text { Zone Exhaust }\end{array}$} \\
\hline & $(\mathrm{Pa})$ & $\left(\right.$ in $\left.\mathrm{H}_{2} \mathrm{O}\right)$ & $(\mathrm{Pa})$ & $\left(\operatorname{ln~} \mathrm{H}_{2} \mathrm{O}\right)$ \\
\hline Wing $C$ to south lobby $(D O)^{b}$ & 20 & 0.08 & 17 & 0.07 \\
\hline Wing $C$ to south lobby $(D C)^{b}$ & 40 & 0.16 & 62 & 0.25 \\
\hline South elevator shaft to south lobby & 0 & 0 & 5 & 0.02 \\
\hline Stairwell 2 to south lobby & -2 & -0.01 & 2 & 0.01 \\
\hline North lobby to south lobby & 15 & 0.06 & 20 & 0.08 \\
\hline South lobby to wing $B(D O)^{b}$ & 12 & 0.05 & 12 & 0.05 \\
\hline South lobby to wing $B(D C)^{b}$ & 22 & 0.09 & 42 & 0.17 \\
\hline
\end{tabular}

For notes see table 19. 
Table 10. Smoke control test of VA Bay Pines Hospital, third floor, zone C

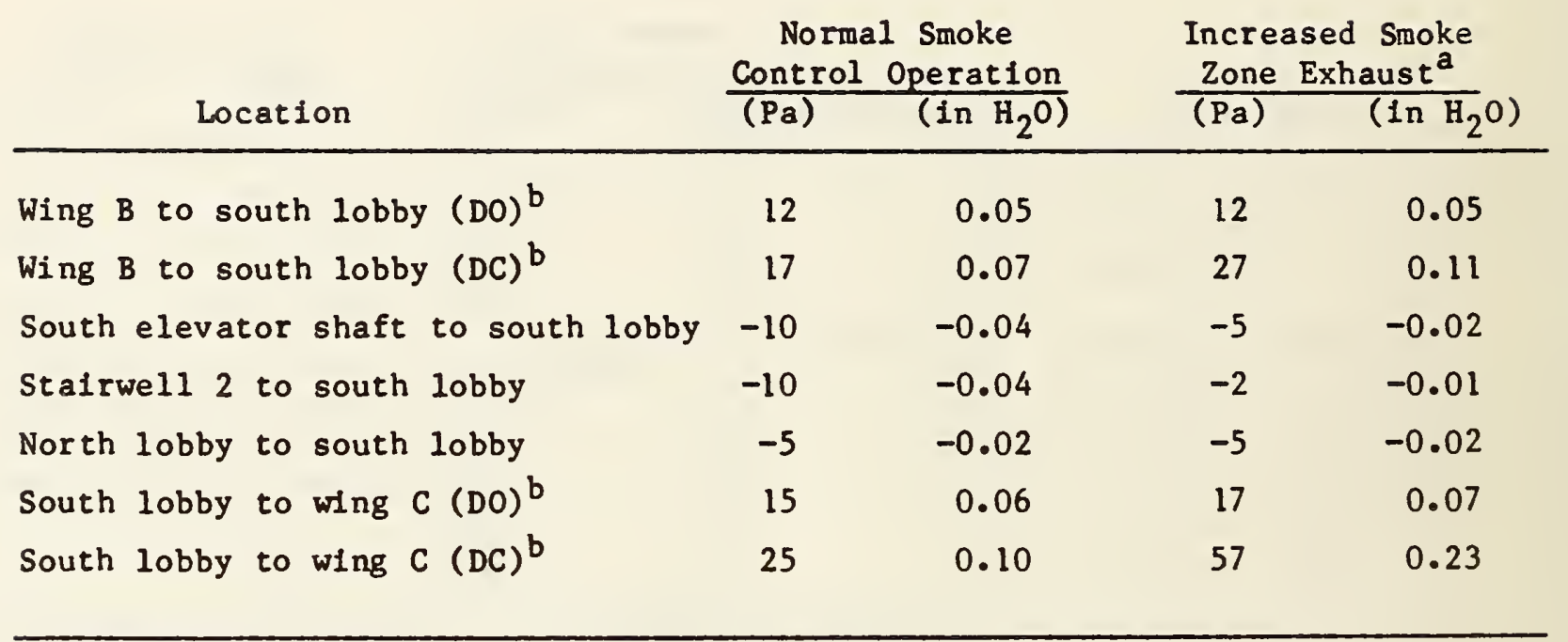

For notes see table 19. 
Table 1l. Smoke control test of VA Bay Pines Hospital, third floor, zone D

\begin{tabular}{|c|c|c|c|c|}
\hline \multirow[b]{2}{*}{ Location } & \multicolumn{2}{|c|}{$\begin{array}{c}\text { Normal Smoke } \\
\text { Control Operation }\end{array}$} & \multicolumn{2}{|c|}{$\begin{array}{l}\text { Increased Smoke } \\
\text { Zone Exhaust }{ }^{a}\end{array}$} \\
\hline & $(\mathrm{Pa})$ & $\left(\right.$ In $\left.\mathrm{H}_{2} \mathrm{O}\right)$ & $(\mathrm{Pa})$ & $\left(\operatorname{ln~} \mathrm{H}_{2} \mathrm{O}\right)$ \\
\hline Wing A to north lobby (DO) ${ }^{b}$ & 10 & 0.04 & 22 & 0.09 \\
\hline Wing $A$ to north lobby $(D C)^{b}$ & 17 & 0.07 & 27 & 0.11 \\
\hline North elevator to north lobby & -7 & -0.03 & 0 & 0 \\
\hline South lobby to north lobby & -2 & -0.01 & 0 & 0 \\
\hline North lobby to wing $A(D O)^{b}$ & 22 & 0.09 & 15 & 0.06 \\
\hline North lobby to wing $A(D C)^{b}$ & 22 & 0.09 & 60 & 0.24 \\
\hline
\end{tabular}

For notes see table 19. 
Table 12. Smoke control test of VA Bay Pines Hospital, fourth floor, zone A

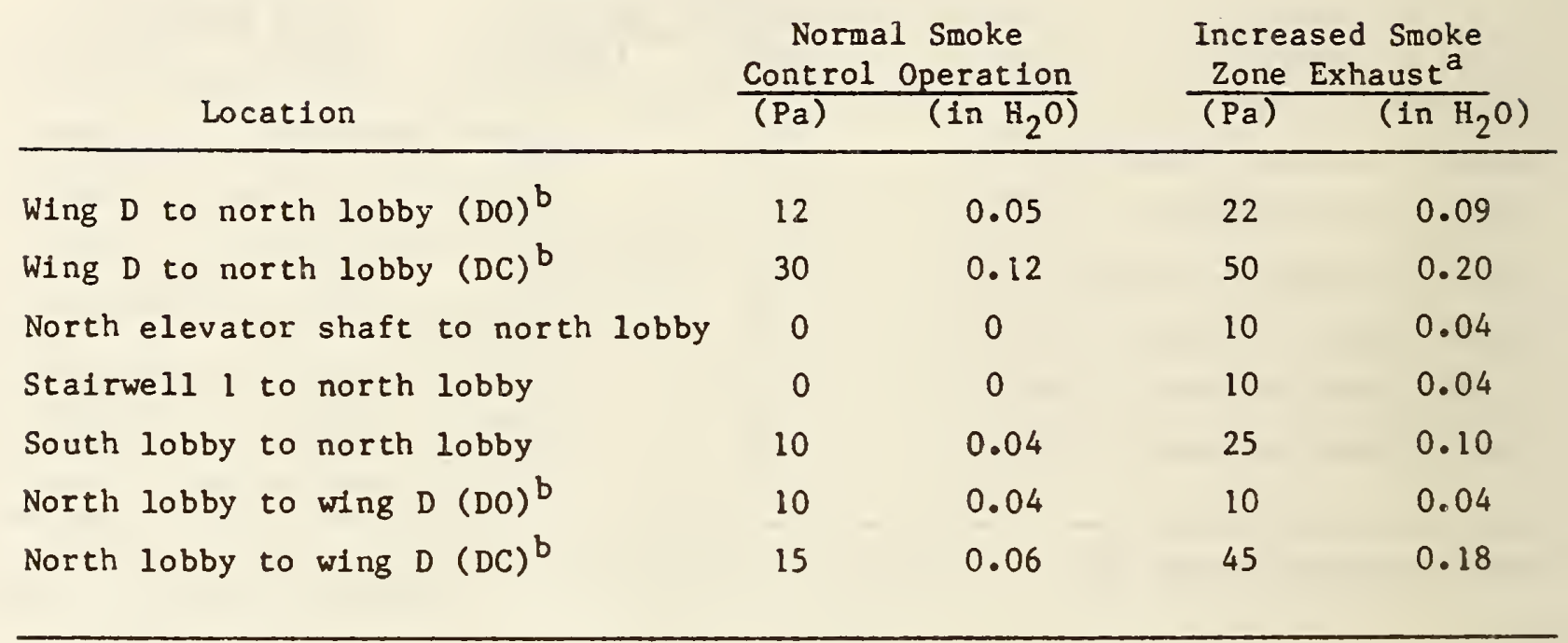

For notes see table 19. 
Table 13. Stoke control test of VA Bay Pines Hospital, fourth floor, zone $B$

Location

Wing $C$ to south lobby (DO $)^{b}$

Wing $C$ to south lobby $(D C)^{b}$

South elevator shaft to south lobby

North lobby to south lobby

South lobby to wing $B(D O)^{b}$

South lobby to wing $B(D C)^{b}$
Increased Smoke

Zone Exhaust ${ }^{\mathrm{a}}$ with

Normal Smoke Control Opertion $(\mathrm{Pa})$

(in $\left.\mathrm{H}_{2} \mathrm{O}\right)$

15

Pressurization

Abcve and Below

$(\mathrm{Pa}) \quad\left({\text { In } \mathrm{H}_{2} \mathrm{O}}^{2}\right)$

\begin{abstract}
0.06
\end{abstract}
0.25
Increased Exhaust

without Pressurization of Floors

$\frac{\text { Above and Below }}{(\mathrm{Pa})}$

For notes see table 19.

0.06

0.19

15

62

7

17

22

$15^{d}$

0

0.05

--

$0.06^{d}$
45

15

0.06

0.24

0.03

7

0.03

0.07

25

0.10

0.09

17

0.07

0.18

47

0.19 
Table 14. Smoke control test of VA Bay Pines Hospital, fourth floor, zone $C$

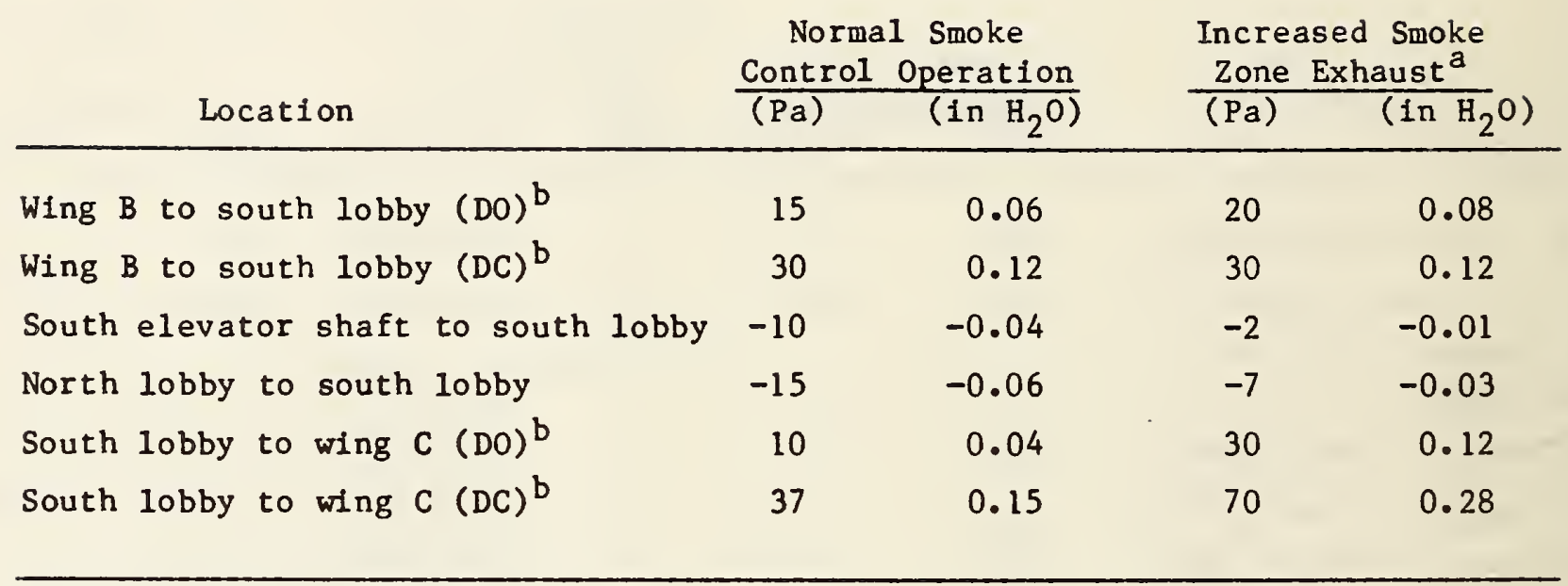

For notes see table 19 . 
Table 15. Smoke control test of VA Bay Pines Hospital, fourth floor, zone D

\begin{tabular}{|c|c|c|}
\hline & $\begin{array}{c}\text { Normal Smoke } \\
\text { Control Operation }\end{array}$ & $\begin{array}{c}\text { Increased Smoke } \\
\text { Zone Exhaust }\end{array}$ \\
\hline Location & $(\mathrm{Pa}) \quad\left(\right.$ in $\left.\mathrm{H}_{2} \mathrm{O}\right)$ & $(\mathrm{Pa}) \quad\left(\ln \mathrm{H}_{2} \mathrm{O}\right)$ \\
\hline
\end{tabular}

\begin{tabular}{|c|c|c|c|c|}
\hline Wing A to north lobby $(\mathrm{DO})^{\mathrm{b}}$ & 15 & 0.06 & 17 & 0.07 \\
\hline Wing A to north lobby $(D C)^{b}$ & 20 & 0.08 & 30 & 0.12 \\
\hline North elevator shaft to north lobby & -7 & -0.03 & 0 & 0 \\
\hline Stalrwell 1 to north lobby & -7 & -0.03 & 0 & 0 \\
\hline South lobby to north lobby & 0 & 0 & 0 & 0 \\
\hline North lobby to wing $D(D O)^{b}$ & 20 & 0.08 & 22 & 0.09 \\
\hline North lobby to wing $D(D C)^{b}$ & 27 & 0.11 & 65 & 0.26 \\
\hline
\end{tabular}

For notes see table 19. 
Table 16. Smoke control test of VA Bay Pines Hospital, fifth floor, zone $A$

\begin{tabular}{|c|c|c|c|c|}
\hline \multirow[b]{2}{*}{ Location } & \multicolumn{2}{|c|}{$\begin{array}{l}\text { Normal Smoke } \\
\text { Control Operation }\end{array}$} & \multicolumn{2}{|c|}{$\begin{array}{c}\text { Increased Smoke } \\
\text { Zone Exhaust }\end{array}$} \\
\hline & $(\mathrm{Pa})$ & $\left(\right.$ in $\left.\mathrm{H}_{2} \mathrm{O}\right)$ & $(\mathrm{Pa})$ & $\left(\right.$ in $\left.\mathrm{H}_{2} \mathrm{O}\right)$ \\
\hline Wing $\mathrm{D}$ to north lobby $(\mathrm{DO})^{\mathrm{b}}$ & 25 & 0.10 & 25 & 0.10 \\
\hline Wing $D$ to north lobby $(D C)^{b}$ & 32 & 0.13 & 50 & 0.20 \\
\hline North elevator shaft to north lobby & 2 & 0.01 & 5 & 0.02 \\
\hline Stairwell 1 to north lobby & 0 & 0 & 7 & 0.03 \\
\hline South lobby to north lobby & 12 & 0.05 & 17 & 0.07 \\
\hline North lobby to wing $A(D O)^{b}$ & 12 & 0.05 & 7 & 0.03 \\
\hline North lobby to wing $A(D C)^{b}$ & 15 & 0.06 & 40 & 0.16 \\
\hline
\end{tabular}

For notes see table 19. 
Table 17. Smoke control test of VA Bay Pines Hospital, fifth floor, zone $B$

\begin{tabular}{|c|c|c|c|c|}
\hline \multirow[b]{2}{*}{ Location } & \multicolumn{2}{|c|}{$\begin{array}{l}\text { Normal Smoke } \\
\text { Control Operation }\end{array}$} & \multicolumn{2}{|c|}{$\begin{array}{c}\text { Increased Smoke } \\
\text { Zone Exhaust }\end{array}$} \\
\hline & $(\mathrm{Pa})$ & $\left(\right.$ in $\left.\mathrm{H}_{2} \mathrm{O}\right)$ & $(\mathrm{Pa})$ & $\left(\operatorname{ln~} \mathrm{H}_{2} \mathrm{O}\right)$ \\
\hline Wing $C$ to south lobby $(D O)^{b}$ & 17 & 0.07 & 17 & 0.07 \\
\hline Wing $c$ to south lobby $(D C)^{b}$ & 27 & 0.11 & 47 & 0.19 \\
\hline South elevator shaft to south lobby & 2 & 0.01 & 7 & 0.03 \\
\hline Stairwe 112 to south lobby & 2 & 0.01 & 0 & 0 \\
\hline North lobby to south lobby & 22 & 0.09 & 40 & 0.16 \\
\hline South lobby to wing $B(D O)^{b}$ & 20 & 0.08 & 20 & 0.08 \\
\hline South lobby to wing $B(D C)^{b}$ & 25 & 0.10 & 57 & 0.23 \\
\hline
\end{tabular}

For notes see table 19. 
Table 18. Smoke control test of VA Bay Pines Hospital, fifth floor, zone $C$

\begin{tabular}{|c|c|c|c|c|}
\hline \multirow[b]{2}{*}{ Location } & \multicolumn{2}{|c|}{$\begin{array}{l}\text { Normal Smoke } \\
\text { Control Operation }\end{array}$} & \multicolumn{2}{|c|}{$\begin{array}{l}\text { Increased Sinoke } \\
\text { Zone Exhaust }\end{array}$} \\
\hline & $(\mathrm{Pa})$ & $\left(\right.$ in $\left.\mathrm{H}_{2} \mathrm{O}\right)$ & $(\mathrm{Pa})$ & $\left(\right.$ In $\left.\mathrm{H}_{2} \mathrm{O}\right)$ \\
\hline Wing B to south lobby & 20 & 0.08 & 22 & 0.09 \\
\hline South elevator shaft to south lobby & -7 & -0.03 & 0 & 0 \\
\hline Stairwell to south lobby & 2 & 0.01 & 50 & 0.20 \\
\hline North lobby to south lobby & -5 & -0.02 & 0 & 0 \\
\hline South lobby to wing $C(D O)^{b}$ & 20 & 0.08 & 15 & 0.06 \\
\hline South lobby to wing $C(D C)^{b}$ & 22 & 0.09 & 75 & 0.30 \\
\hline
\end{tabular}

For notes see table 19. 
Table 19. Smoke control test of VA Bay Pines Hospital, fifth floor, zone D

\begin{tabular}{|c|c|c|}
\hline & $\begin{array}{c}\text { Normal Smoke } \\
\text { Control Operation }\end{array}$ & $\begin{array}{l}\text { Increased Smoke } \\
\text { Zone Exhaust }\end{array}$ \\
\hline & $(\mathrm{Pa}) \quad\left(\right.$ in $\left.\mathrm{H}_{2} \mathrm{O}\right)$ & $(\mathrm{Pa}) \quad\left(\mathrm{in} \mathrm{H}_{2} \mathrm{O}\right)$ \\
\hline
\end{tabular}

Wing A to north lobby (DO) ${ }^{\mathrm{b}}$ 25

0.10

25

0.10

Wing $A$ to north lobby (DC) ${ }^{b}$

30

0.12

45

0.18

South elevator to north lobby

$-17$

$-0.07$

$-7$

$-0.03$

Stafrwe11 l to north lobby

$-15$

$-0.06$

2

0.01

South lobby to north lobby

$-27$

$-0.11$

$-12$

$-0.05$

North lobby to wing D (DO) ${ }^{b}$

17

0.07

27

0.11

North lobby to wing $D(D C)^{b}$

27

0.11

0.23

Notes:

a. Exhaust air increased from the smoke zone by blocking an exhaust inlet located inside the interstitial space.

b. Frequently, the airflow was sufficient to hold doors open a few Inches. Pressure difference measurements made under this condition are denoted (DO). Additional measurements were made where the doors were held closed (DC).

c. Operation of smoke control system was without pressurization of zones on floors above and below and with increased smoke zone exhaust due to blocking of interstitial space exhaust.

d. Insufficient air flow to hold door open. 

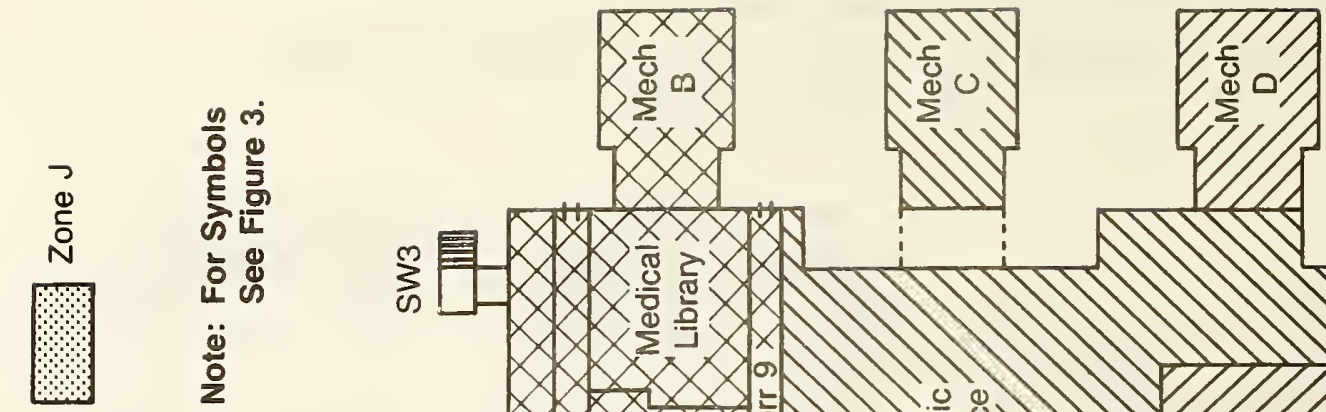

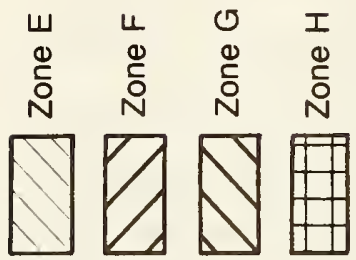

$4 \times \times \times$

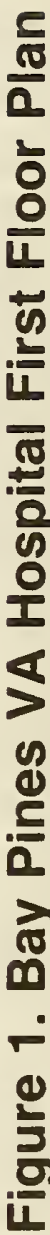
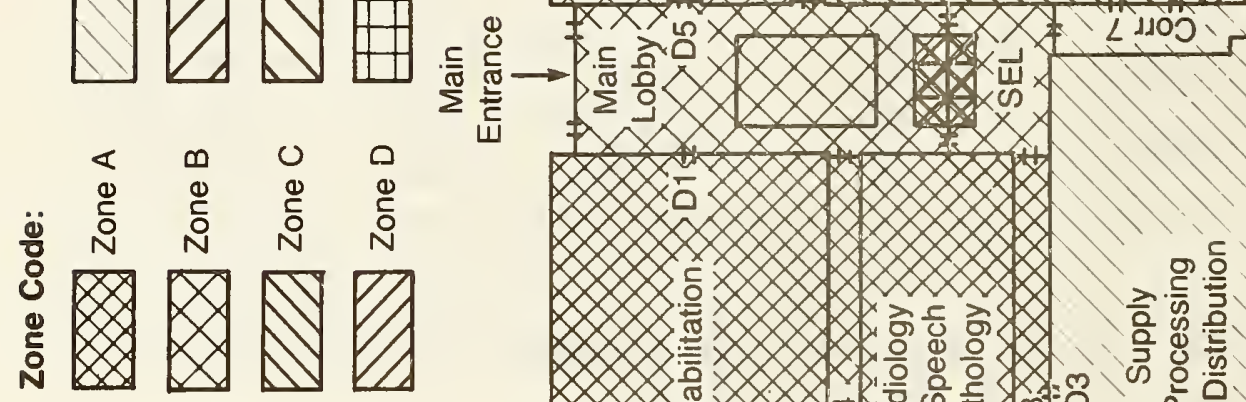

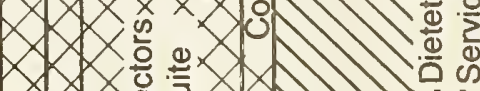

120

(1)

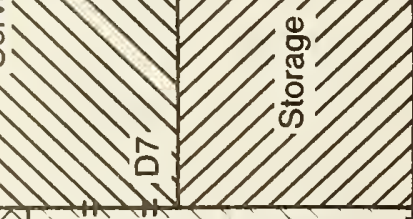

口冒京
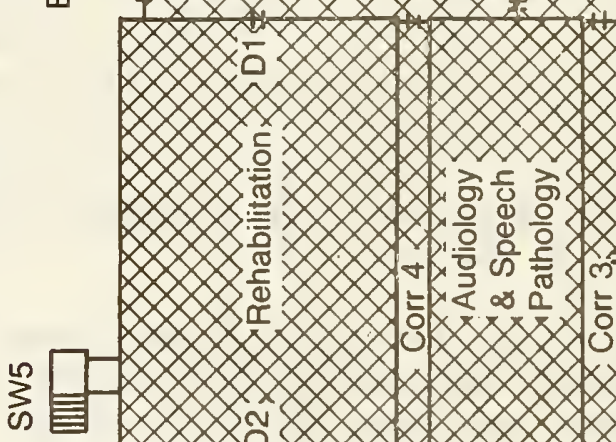

ג

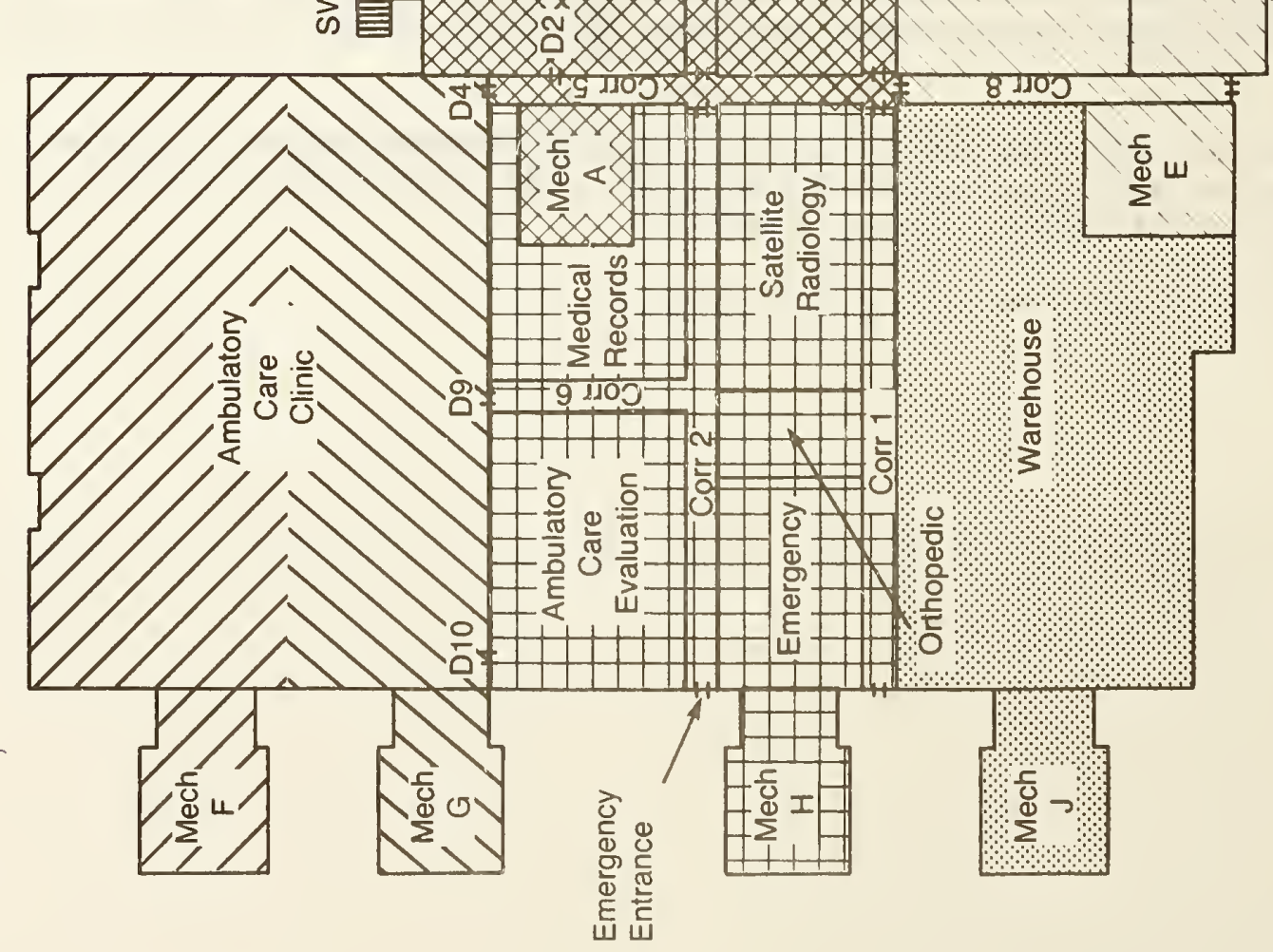

圈 $\sum_{\text {心 }}^{\circ}$ 


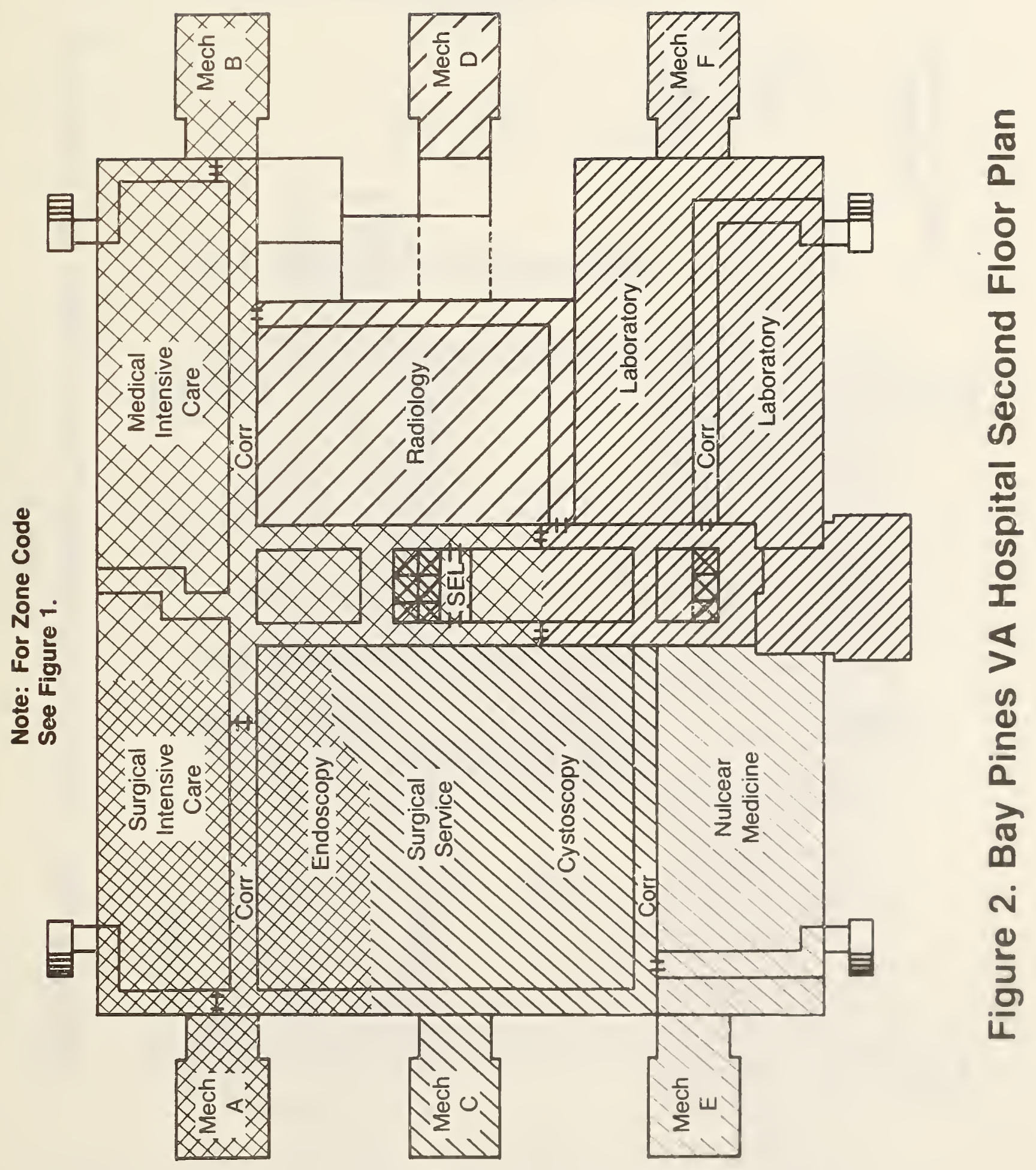




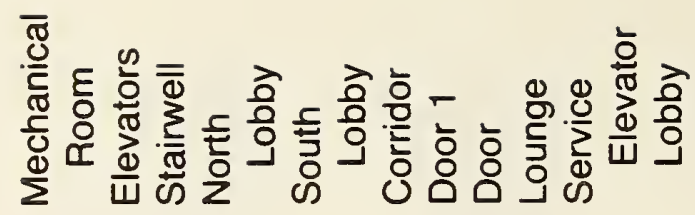

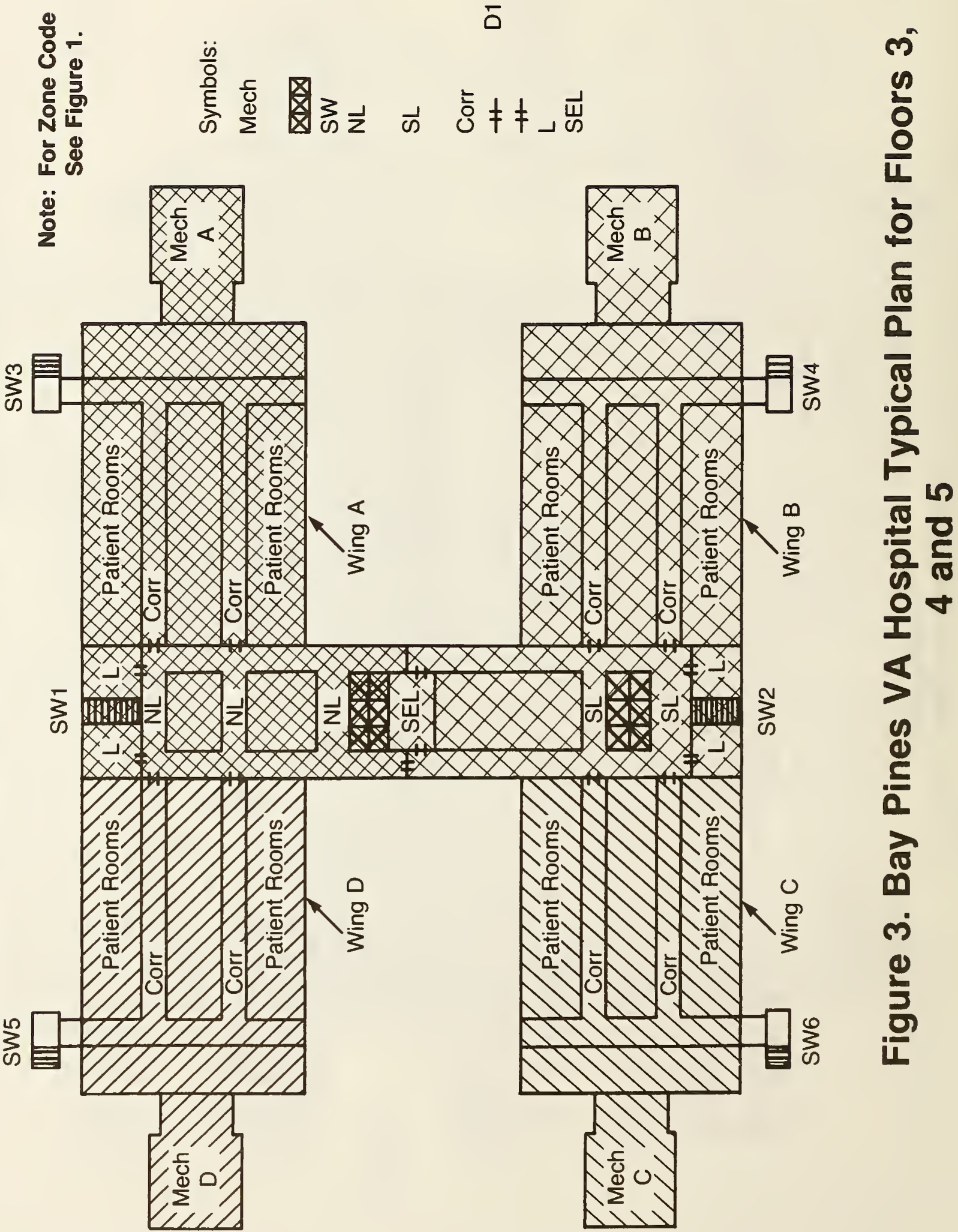




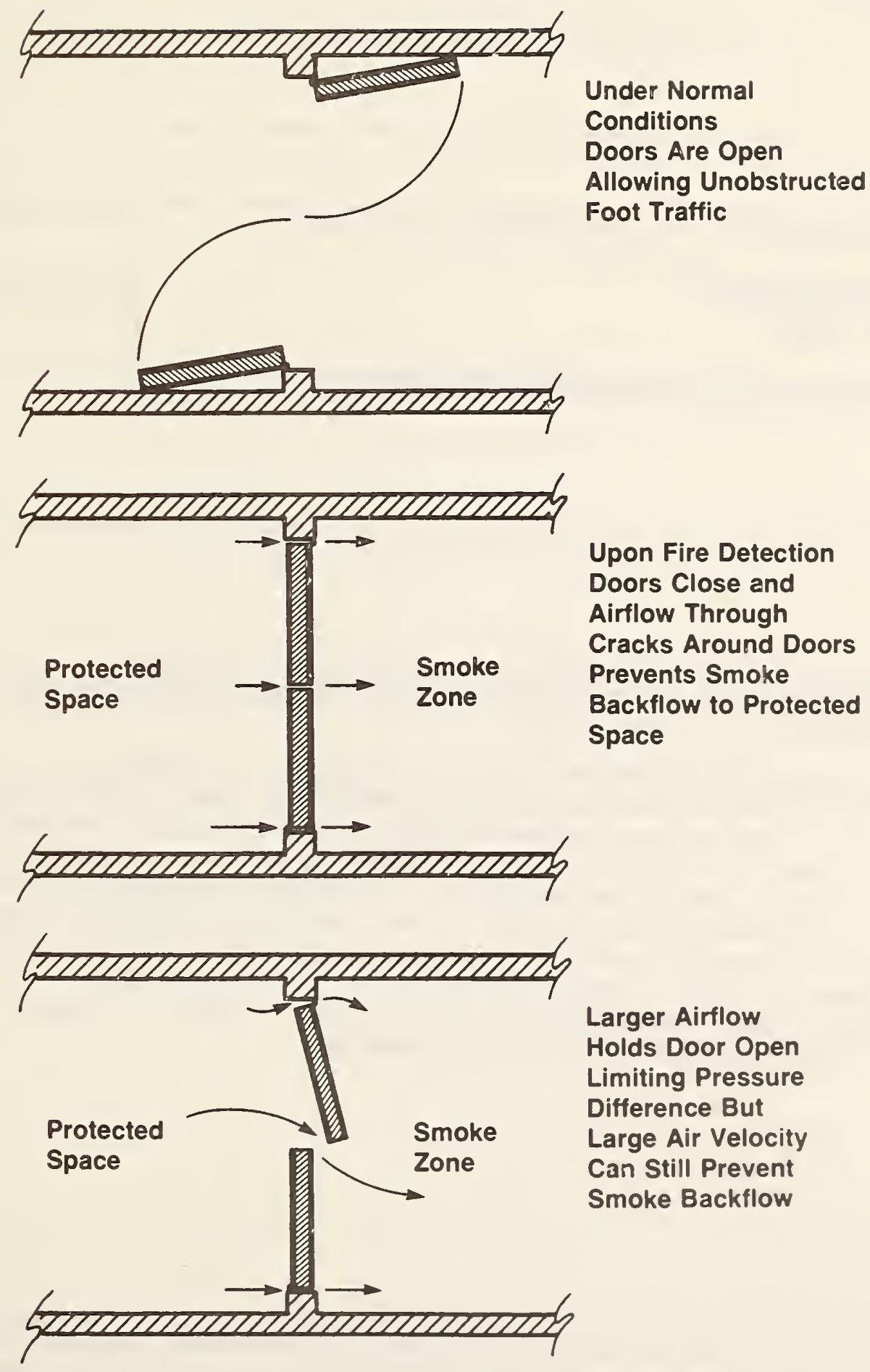

Figure 4. Operations of Double Egress Doors in Smoke Control System 
NBS.114A (REV. 2-8C)

U.S. DEPT. OF COMM.

BIBLIOGRAPHIC DATA

SHEET (See instructions)

1. PUBLICATION OR REPORT NO.

NBSIR $84-2868$

2. Performing Organ. Report Nod 3. Publication Date

May 1984

4. TITLE AND SUBTITLE

Field Tests of the Smoke Control System at the Bay Pines VA Hospital

5. $\operatorname{AUTHOR}(S)$

John H. Klote

6. PERFORMING ORGANIZATION (If joint or other than NBS, see instructions)

NATIONAL BUREAU OF STANDARDS

DEPARTMENT OF COMMERCE

WASHINGTON, D.C. 20234

9. SPONSORING ORGANIZATION NAME AND COMPLETE ADDRESS (Street, City, State, ZIP)

7. Contract/Grant No.

8. Type of Report \& Period Covered

10. SUPPLEMENTARY NOTES

Document describes a computer program; SF-185, FIPS Software Summary, is attached.

11. ABSTRACT (A 200-word or less factual summary of most significant information. If document includes a significant bibliography or literature survey, mention it here)

The Veterans Administration (VA) has sponsored a project at the Center for Fire Research of the National Bureau of Standards to study smoke control in VA hospitals and to develop new design approaches and methods of acceptance testing. This paper is the first report of this project, and it presents the results of a field test on the VA Bay Pines Hospital. In general the smoke control systems at this hospital performed well, however, there were some problems. These problems are discussed along with specific recommendations for their corrections and general recommendations to prevent similar problems in future hospitals. It was observed that the bidirectional double doors in the hospital acted in a manner similar to barometric dampers to limit pressure differences.

12. KEY WORDS (Six to twelve entries; alphabetical order: capitalize only proper names; and separate key words by semicolons) Air movement; field tests; hospitals; interstitial space; pressurization; smoke control; smoke detector.

\section{AVAILABILITY}

[X] Unlimited

[ For Official Distribution. Do Not Release to NTIS

$\square$ Order From Superintendent of Documents, U.S. Government Printing Office, Washington, D.C. 20402.

$[X]$ Order From National Technical Information Service (NTIS), Springfield, VA. 2216I
14. NO. OF

PRINTED PAGES

50

15. Price 

